\title{
Efektifitas Model Pembelajaran Problem Base Learning Berbantukan Multimedia Terhadap Kemampuan Pemecahan Masalah Siswa
}

\section{Effectiveness Of Using Multimedia with Problem Base Learning Models to Increase Students Problem Solving Skill}

\author{
Herijon Muhammad Syahril ${ }^{1}$, Ngatijoº ${ }^{2}$ Muhaimin ${ }^{2}$ \\ ${ }^{1}$ Mahasiswa Program Studi Magister Pendidikan Kimia PPs Universitas Jambi, Jambi \\ 2 Dosen Program Studi Magister Pendidikan Kimia PPs Universitas Jambi, Jambi
}

\section{A B S T R A K.}

Penelitian ini bertujuan untuk memperoleh informasi tentang efektivitas pembelajaran. Metode penelitian yang digunakan adalah penelitian campuran jenis Exploratory Sequential Design. Penelitian ini akan mendapatkan data kualitatif dan kuantitatif yang keduanya akan digabung untuk memperoleh data yang lebih rinci dan saling menguatkan. Berdasarkan hasil temuan pada penelitian ini didapatkan bahwa: (1) Kemampuan pemecahan masalah pada kelas PBL berbantuan multimedia lebih tinggi dibandingkan dengan kelas PBL. (2) Multimedia berpengaruh terhadap kemampuan pemecahan masalah siswa dengan nilai uji $\mathrm{t}=0.007$. (3) Ketuntasan siswa pada kelas PBL berbantukan multimedia mencapai $88 \%$ sedangkan pada kelas PBL mencapai 50\%. Dengan demikian dapat disimpulkan bahwa penerapan model PBL berbantuan multimedia efektif meningkatkan kemampuan pemecahan masalah siswa.

\section{$A B S T R A C T$}

This study aims to obtain information about the effectiveness of learning in class XI IPA SMAN 10 Jambi city. The research method used is a mixture of Exploratory Sequential Design. This research will obtain qualitative and quantitative data which will both be combined to obtain more detailed and mutually reinforcing data. Based on the findings in this study it was found that: (1) The ability of problem-solving in PBL class with multimedia assisted was higher than in PBL class. (2) Multimedia has an effect on students' problem solving abilities with a test score of $-t=0.007$. (3) Students completeness in multimedia assisted PBL classes reaches $88 \%$ while in PBL classes reach 50\%. Thus, it can be concluded that the application of multimedia-assisted PBL models effectively improves students' problem-solving abilities.

Kata kunci : Efektifitas, Multimedia, Problem Base Learning

Keyword : Effectiveness, Multimedia, Problem Base Learning, Problem Solving Skill

I N F O A R T I K E L

Received: 3 Sept 2019;

Revised: 31 Okt 2019

Accepted: 07 Nov 2019 coresponding author: sworddeck3@gmail.com

DOI: https://doi.org/jisic.v11i2.7433 


\section{PENDAHULUAN}

Pembelajaran kimia untuk tingkat SMA sederajat mempelajari segala sesuatu tentang zat yang meliputi komposisi, perubahan, dinamika, struktur dan sifat, dan energitika zat yang banyak bersifat abstrak yang membutuhkan kreativitas dan penalaran. Terdapat dua aspek utama dalam pembelajaran kimia yang tidak bisa dipisahkan, yaitu kimia sebagai produk (berupa fakta, konsep, prinsip, hukum, dan teori) dan kimia sebagai proses berupa kerja ilmiah. Pada pembelajaran tingkat SMA/sederajat, ilmu kimia yang dipelajarkan mencangkup kelima cabang utama tersebut yang disampaikan secara umum. Pembelajaran kimia ditingkat SMA/ sederajat tidak hanya penyampaian teori saja melainkan juga dilakukan praktik laboratorium untuk meningkatkan pengetahuan konsep siswa terhadap materi yang diajarkan dan memperkaya keterampilan siswa dalam pengolahan di laboratorium.

Wawancara dilakukan sebagai observasi awal penelitian kepada guru-guru kimia di SMAN 10 kota Jambi, disampaikan oleh responden bahwa perlu ditingkatkannya hasil belajar siswa dan menyarankan agar hasil belajar yang ditingkatkan adalah kemampuan pemecahan masalah. Hal ini berguna untuk meningkatkan KKM siswa sehingga terbiasa dengan soal-soal dengan tingkat kognitif $\mathrm{C} 4$ keatas. Hal demikian sangat perlu diperhatikan untuk meningkatkan keterampilan siswa dalam mengatasi gejala kimia yang biasa ditemui di kehidupan sehari-hari. Selain itu juga disampaikan bahwa diperlukan model pembelajaran yang cocok untuk meningkatkan hasil belajar tersebut. Disampaikan bahwa model tersebut adalah model pembelajaran yang dapat membuat siswa aktif dalam pembelajaran dan aktif berdiskusi untuk memecahkan masalah ketika diberikan suatu masalah. Selain itu model tersebut juga dapat digunakan dengan metode diskusi dan eksperimen.

Model pembelajaran yang dipilih dalam penelitian ini adalah model Problem
Base Learning (PBL). Fathurrohman (2015) menyatakan model pembelajaran PBL adalah model pembelajaran kooperatif yang berpusat kepada siswa (student center). PBL menekankan pada proses pembelajaran yang menggunakan masalah nyata yang selalu dihadapi siswa sehari-hari yang tidak terstruktur dan bersifat terbuka sebagai konteks bagi siswa untuk membangun pengetahuan baru, mengembangkan keterampilan berpikir kritis dan penyelesaian masalah. Penggunaan model PBL dalam penerapan pembelajaran abad 21 dirasa bagus dan sangat fleksibel dapat dibelajarkan pada mata pelajaran kimia. Dijelaskan oleh Perdana, Jumadi dan Rosana (2019) bahwa model PBL cocok diintegrasikan dengan kemampuan berpikir analisis dan argumentasi ilmiah. Baik kemampuan berpikir analisis, argumentasi ilmiah dan kemampuan pemecahan masalah merupakan keterampilan yang dibutuhkan pada abad 21. Qian dan Clark (2016) juga mengungkapkan bahwa pembelajaran yang berbasis permainan dan media efektif dalam mengembangkan keterampilan siswa pada abad 21.

Berdasarkan wawancara yang dilakukan kepada siswa XI IPA SMAN 10 kota Jambi, disampaikan bahwa siswa sangat tertarik apabila pembelajaran kimia yang diajarkan menggunakan multimedia, baik berupa gambar, video, suara dan teks. Penggunaan multimedia dirasa lebih menarik dan mempermudah memahami materi yang disampaikan guru.

\section{METODE PENELITIAN}

Penelitian ini dilakukan di kelas XI SMAN 10 kota Jambi pada semester genap tahun pelajaran 2018/2019. Penelitian yang digunakan adalah penelitian campuran jenis Exploratory Sequential Design. Menurut Creswell (2012) bahwa terdapat enam jenis rancangan dari penelitian campuran ini, dan salah satunya adalah Exploratory Sequential Design. Variabel bebas dalam penelitian ini adalah penggunaan multimedia sedangkan variable terikatnya adalah model PBL dan kemampuan 
pemecahan masalah siswa. Penelitian menggunakan dua kelas yakni kelas eksperimen 1 dan kelas eksperimen 2.

Penelitian diawali dengan validasi instrumen-instrumen yang digunakan lalu penentuan kelas eksperimen 1 dan kelas eksperimen 2 berdasarkan random sampling. Selanjutnya dilakukan pembelajaran PBL perbantukan multimedia dan PBL tanpa multimedia pada masing-masing kelas sebanyak tiga kali pertemuan. Selanjutnya dilakukan pengujian dengan menggunakan soal kemampuan pemecahan masalah yang telah divalidasi.

Instrumen lain yang digunakan adalah Lembar observasi untuk guru dan siswa serta pedoman wawancara untuk guru dan siswa. Masing-masing instrumen telah divalidasi oleh tim ahli dan dinyatakan layak untuk digunakan.

Pengolahan dari data kualitatif yang didapatkan akan di tabulasi dan diintrepretasikan untuk memperoleh data uraian. Pengolahan dari data kualitatif yang didapatkan akan diuji melalui uji statistik menggunakan bantuan software SPSS 20.

\section{HASIL DAN PEMBAHASAN}

Hasil instrumen lembar observasi guru dan siswa dapat dilihat pada tabel 1 dan tabel 2.

Tabel 1. Hasil instrumen lembar observasi guru

\begin{tabular}{lcccc}
\hline \multirow{2}{*}{$\begin{array}{c}\text { Pert- } \\
\text { emuan }\end{array}$} & \multicolumn{2}{c}{$\begin{array}{c}\text { Kelas XI IPA 1 } \\
\text { (eksperimen 1) }\end{array}$} & \multicolumn{2}{c}{$\begin{array}{c}\text { Kelas XI IPA 2 } \\
\text { (eksperimen 2) }\end{array}$} \\
\cline { 2 - 5 } & $\begin{array}{c}\text { Jumlah } \\
\text { skor }\end{array}$ & $\begin{array}{c}\text { Persentas } \\
\text { e (\%) }\end{array}$ & $\begin{array}{c}\text { Jumlah } \\
\text { skor }\end{array}$ & $\begin{array}{c}\text { Persentase } \\
(\%)\end{array}$ \\
\hline Pertama & 22 & 75 & 20 & 78,6 \\
Kedua & 23 & 82.1 & 24 & 85,7 \\
Ketiga & 26 & 92,9 & 26 & 92,9 \\
\hline Jumlah & 71 & - & 70 & - \\
\hline Rata- & 23,6 & 84,5 & 23,3 & 83,3 \\
Rata & & & & \\
\hline
\end{tabular}

Tabel 2. Hasil instrumen lembar observasi siswa

\begin{tabular}{lcccc}
\hline \multirow{2}{*}{$\begin{array}{c}\text { Perte- } \\
\text { muan }\end{array}$} & \multicolumn{2}{c}{$\begin{array}{c}\text { Kelas XI IPA 1 } \\
\text { (eksperimen) }\end{array}$} & \multicolumn{2}{c}{$\begin{array}{c}\text { Kelas XI IPA 2 } \\
\text { (eksperimen 2) }\end{array}$} \\
\cline { 2 - 5 } & $\begin{array}{c}\text { Jumlah } \\
\text { skor }\end{array}$ & $\begin{array}{c}\text { Persentase } \\
(\%)\end{array}$ & $\begin{array}{c}\text { Jumlah } \\
\text { skor }\end{array}$ & $\begin{array}{c}\text { Persentase } \\
(\%)\end{array}$ \\
\hline Pertama & 691 & 82,9 & 695 & 82,7 \\
Kedua & 728 & 86,7 & 719 & 85,6 \\
Ketiga & 743 & 88,5 & 731 & 87,0 \\
Jumlah & 2162 & - & 2145 & - \\
\hline Rata- & 720,7 & 85,8 & 715 & 85,1 \\
Rata & & & & \\
\hline
\end{tabular}

Terlihat bahwa terdapat perbedaan skor antara kelas XI IPA 1 (eksperimen 1) dengan kelas XI IPA 2 (eksperimen 2) pada setiap pertemuannya baik melalui pelaksanaan pembelajaran oleh guru maupun siswa. Rata-rata pelaksanaan pembelajaran oleh siswa pada kelas XI IPA 1 (eksperimen 1) adalah $85,8 \%$ dan pada kelas XI IPA 2 (eksperimen 2) adalah 85,1\%.

Berdasarkan data lembar observasi dan butir indikator pemecahan masalah, akan didapatkan data pemetaan setiap indikator pada setiap pertemuannya, seperti pada tabel 3 .

Pada penelitian ini dilakukan pula uji -t untuk melihat pengaruh penggunaan multimedia dalam pembelajaran PBL. Sebelum melakukan uji -t, dilakukan pula uji prasyarat yakni menguji normalitas dan homogenitas data yang diperoleh. Pengujian ini dilakukan dengan bantuan software SPSS 20. Hasil perhitungannya dapat dilihat pada tabel 4, tabel 5 dan tabel 6 .

Dalam uji-t tersebut, didapatkan nilai signifikansi sebesar 0,007 dapat dilihat pada tabel 6. Nilai tersebut lebih kecil dari 0,05. Maka dapat ditarik kesimpulan bahwa terdapat pengaruh pemberian multimedia terhadap kemampuan pemecahan masalah.

Perolehan hasil pengujian soal kemampuan pemecahan masalah didapatkan data seperti pada tabel 7 . 
Tabel 3. Intrepretasi lembar observasi

\begin{tabular}{|c|c|c|c|}
\hline \multirow{2}{*}{$\begin{array}{c}\text { Aktifitas } \\
\text { Siswa }\end{array}$} & \multicolumn{2}{|c|}{ Kelas } & \multirow[t]{2}{*}{ Interpretasi } \\
\hline & $\begin{array}{c}\text { Eksperi } \\
\text { men } 1\end{array}$ & $\begin{array}{c}\text { Eksperi } \\
\text { men } 2\end{array}$ & \\
\hline P1 & 103 & 103 & \multirow{4}{*}{$\begin{array}{l}\text { Kelas eksperimen } 1 \\
\text { lebih unggul dalam } \\
\text { menganalisis masalah } \\
\text { yang ada pada LKS } \\
\text { dibandingkan kelas } \\
\text { eksperimen 2 }\end{array}$} \\
\hline $\mathrm{P} 2$ & 107 & 98 & \\
\hline P3 & 115 & 105 & \\
\hline Jumlah & 325 & 306 & \\
\hline $\mathrm{P} 1$ & 99 & 98 & \multirow{4}{*}{$\begin{array}{lr}\text { Kelas } & \text { eksperimen } \\
\text { sedikit lebih unggul } \\
\text { dalam } & \text { membentuk } \\
\text { kelompok } & \text { dan } \\
\text { berdiskusi } & \\
\text { dibandingkan } & \text { kelas } \\
\text { eksperimen 2 } & \end{array}$} \\
\hline $\mathrm{P} 2$ & 102 & 101 & \\
\hline P3 & 105 & 104 & \\
\hline Jumlah & 306 & 303 & \\
\hline P1 & 97 & 93 & \multirow{8}{*}{$\begin{array}{lr}\text { Kelas } & \text { eksperimen 1 } \\
\text { lebih unggul dalam } \\
\text { mencari } & \text { informasi } \\
\text { lanjutan } & \text { mengenai } \\
\text { masalah } & \text { kelompok } \\
\text { dibanding } & \text { kelas } \\
\text { eksperimen } 2 & \\
\text { Kelas eksperimen 2 } \\
\text { sedikit lebih unggul } \\
\text { dalam menanggapi } \\
\text { informasi } \\
\text { diperoleh dibandingkan } \\
\text { kelas eksperimen 1 }\end{array}$} \\
\hline $\mathrm{P} 2$ & 106 & 99 & \\
\hline P3 & 109 & 105 & \\
\hline Jumlah & 312 & 297 & \\
\hline P1 & 97 & 98 & \\
\hline $\mathrm{P} 2$ & 102 & 100 & \\
\hline P3 & 103 & 105 & \\
\hline Jumlah & 302 & 303 & \\
\hline P1 & 101 & 94 & \multirow{8}{*}{\begin{tabular}{lr} 
Kelas & \multicolumn{2}{c}{ eksperimen 1} \\
lebih unggul dalam \\
diskusi lanjutan dan \\
menuliskan & solusi \\
kelompok & kedalam \\
LKS dibandingkan \\
dengan \\
eksperimen 2 \\
$\begin{array}{l}\text { Kedua kelas } \\
\text { kemampuan }\end{array}$ \\
menyajikan \\
diskusi kelompok dan \\
menanggapi \\
pertanyaan yang sama
\end{tabular}} \\
\hline $\mathrm{P} 2$ & 101 & 106 & \\
\hline P3 & 106 & 100 & \\
\hline Jumlah & 308 & 300 & \\
\hline P1 & 101 & 98 & \\
\hline $\mathrm{P} 2$ & 104 & 104 & \\
\hline P3 & 103 & 106 & \\
\hline Jumlah & 308 & 308 & \\
\hline $\mathrm{P} 1$ & 103 & 102 & \multirow{4}{*}{$\begin{array}{lr}\text { Kelas eksperimen } 1 \\
\text { lebih unggul dalam } \\
\text { menyimpulkan hasil } \\
\text { diskusi dibandingkan } \\
\text { dengan } & \text { kelas } \\
\text { eksperimen } 2 & \end{array}$} \\
\hline $\mathrm{P} 2$ & 112 & 110 & \\
\hline P3 & 107 & 103 & \\
\hline Jumlah & 322 & 315 & \\
\hline
\end{tabular}

Tabel 4. Uji normalitas data

\begin{tabular}{|c|c|c|c|}
\hline \multicolumn{4}{|c|}{ One-Sample Kolmogorov-Smirnov Test } \\
\hline & \multicolumn{2}{|c|}{ XI IPA 1 (eksperimen 1) } & $\begin{array}{c}\text { XI IPA 2 } \\
\text { (eksperimen 2) }\end{array}$ \\
\hline $\mathrm{N}$ & & 30 & 30 \\
\hline Normal & Mean & 81.33 & 76.33 \\
\hline Parameters ${ }^{\mathrm{a}, \mathrm{b}}$ & Std. Deviation & 13.89203 & 12.00575 \\
\hline & Absolute & .137 & .153 \\
\hline $\begin{array}{l}\text { Most Extreme } \\
\text { Differences }\end{array}$ & Positive & .090 & .153 \\
\hline & Negative & -.137 & -.147 \\
\hline $\begin{array}{l}\text { Kolmogorov- } \\
\text { Smirnov Z }\end{array}$ & & .753 & .840 \\
\hline $\begin{array}{l}\text { Asymp. Sig. (2- } \\
\text { tailed) }\end{array}$ & & .623 & .480 \\
\hline
\end{tabular}

Tabel 5. Uji homogenitas data

Test of Homogeneity of Variances

\begin{tabular}{cccc}
\hline Levene Statistic & $\mathrm{df1}$ & $\mathrm{df2}$ & Sig. \\
.197 & 1 & 58 & .659 \\
\hline
\end{tabular}

Tabel 6. Uji - $t$

\begin{tabular}{|c|c|c|c|c|c|c|}
\hline \multirow{3}{*}{\multicolumn{2}{|c|}{ Model }} & \multicolumn{4}{|c|}{ Coefficients $^{\mathrm{a}}$} & \multirow{3}{*}{ Sig. } \\
\hline & & \multicolumn{2}{|c|}{$\begin{array}{l}\text { Unstandardized } \\
\text { Coefficients }\end{array}$} & \multirow{2}{*}{$\begin{array}{c}\text { Standardized } \\
\text { Coefficients } \\
\text { Beta } \\
\end{array}$} & \multirow[t]{2}{*}{ t } & \\
\hline & & B & Std. Error & & & \\
\hline \multirow[b]{2}{*}{1} & (Constant) & 90.66 & 5.300 & & 17.106 & .000 \\
\hline & $\begin{array}{l}\text { MULTIME } \\
\text { DIA }\end{array}$ & -9.33 & 3.352 & -.343 & -2.784 & .007 \\
\hline
\end{tabular}

Tabel 7. Jumlah siswa yang lulus KKM berdasarkan soal kemampuan pemecahan masalah

\begin{tabular}{|c|c|c|}
\hline & $\begin{array}{l}\text { Kelas XI IPA } 1 \\
\text { (Eksperimen 1) }\end{array}$ & $\begin{array}{l}\text { Kelas XI IPA } 2 \\
\text { (eksperimen 2) }\end{array}$ \\
\hline $\begin{array}{c}\text { Jumlah siswa } \\
\text { dengan nilai } \geq \\
75\end{array}$ & 23 & 15 \\
\hline $\begin{array}{c}\text { Jumlah siswa } \\
\text { dengan nilai }< \\
75\end{array}$ & 7 & 15 \\
\hline Total & 30 & 30 \\
\hline $\begin{array}{c}\text { Persentase } \\
\text { Lulus KKM }\end{array}$ & $76,67 \%$ & $50 \%$ \\
\hline
\end{tabular}

Dari data pada tabel 7 dapat dilihat bahwa perolehan ketuntasan siswa pada kelas eksperimen 1 sebanyak 23 siswa dengan persentase lulusan diatas KKM adalah $76,67 \%$ sedangkan pada kelas eksperimen 2 sebanyak 15 siswa dengan persentase lulusan diatas KKM adalah $50 \%$.

Keseluruhan hasil menjelaskan bahwa kelas eksperimen 1 (PBL berban- 
tukan multimedia) lebih unggul dibandingkan dengan kelas eksperimen 2 (PBL). Penggunaan multimedia yang digunakan dalam pembelajaran dapat meningkatkan kemampuan pemecahan masalah siswa.

Penelitian serupa telah dilakukan oleh Lestari, Nizaruddin dan Murtianto (2017) yang meneliti tentang efektivitas model PBL berbantuan media terhadap prestasi belajar matematika. Dalam penelitian tersebut menunjukkan terdapat perbedaan efektivitas model PBL berbatuan media dengan pembelajaran konvensional terhadap prestasi belajar siswa matematika. Penelitian seperti ini juga telah dilakukan oleh Saharsa, Qaddafi, \& Baharuddin (2018) dalam bentuk Quasi Eksperimen dengan menggunakan kelas kontrol, memperoleh hasil bahwa pemahaman konsep siswa di kelas eksperimen yang diajarkan menggunakan model pembelajaran Problem Based Learning dengan memanfaatkan video base laboratory berada pada kategori tinggi, dengan presentase $80 \%$ terdapat peningkatan pemahaman konsep fisika siswa.

Penelitian lain dilakukan oleh Karimah, Rusdi dan Fachruddin (2017) menggunakan media software animasi berbasis multimedia interaktif pada materi garis dan sudut. Hasil penelitian tersebut menunjukkan efektivitas multimedia masuk kategori sangat efektif. Penelitian seperti ini dilakukan juga di perguruan tinggi oleh Untarti (2015) yang meneliti tentang efektifitas PBL terhadap kemampuan pemecahan masalah mahasiswa pada mata kuliah statistika inferensia. Penelitian ini dilakukan dengan dua kelas, salah satu kelas dibelajarkan dengan model PBL dan kelas lainnya dengan pembelajaran langsung (Direct Instruction). Dari hasil penelitian didapatkan bahwa model PBL efektif digunakan untuk mengembangkan kemampuan pemecahan masalah matematis mahasiswa pada mata kuliah statistika inferensia.

Diungkapkan oleh Allen dan Mayer (2009) tentang teori kognitif mengenai multimedia learning yaitu dual-channel (saluran ganda). Asumsi saluran ganda ini mengasumsikan bahwa dalam memproses informasi manusia memiliki saluran yang terpisah yaitu materi visual dan materi auditor. Informasi berupa kata-kata akan ditangkap oleh mata dan telinga, sedangkan informasi berupa gambar akan diterima oleh mata. Informasi akan diseleksi oleh memori sensorik, selanjutnya diteruskan ke memori kerja. Di dalam memori kerja inilah informasi diorganisasikan dan diintegrasikan yang selanjutnya diteruskan ke memori jangka panjang. Oleh karenanya, penggunaan multimedia dalam pembelajaran menggunakan model Problem Base Learning akan sangat membantu dan lebih efektif meningkatkan kemampuan pemecahan masalah siswa.

Penggunaan multimedia dalam belajar akan membangkitkan keinginan belajar siswa, membangkitkan motivasi belajar, meningkatkan minat yang baru, dan berpengaruh terhadap psikologis siswa. Penggunaan multimedia memang akan dapat meningkatkan antusias siswa dalam belajar sehingga hasil belajar siswa (dalam hal ini adalah kemampuan pemecahan masalah) akan lebih baik dibandingkan pembelajaran tanpa multimedia. Disamping meningkatkan antusias siswa dalam belajar, penggunaan multimedia juga akan meningkatkan kejelasan materi pembelajaran sehingga siswa akan lebih mudah untuk memahami dan mengingat materi pelajaran yang diberikan.

\section{KESIMPULAN}

Berdasarkan hasil penelitian, dapat disimpulkan bahwa media pembelajaran berbasis multimedia yang digunakan efektif untuk meningkatkan keterampilan pemecahan masalah siswa. 


\section{DAFTAR RUJUKAN}

Allen, N.J., dan Meyer, J.P. (2009). The measurement and antecendents of affective, continuance and normative commitment to the organization. Journal of Occupational Psychology. 63(1), 1-18

Creswell, J. W. (2012). educational research (4th ed). USA: Pearson.

Fathurrohman, M. (2015). Model-model pembelajaran inovatif. Yogyakarta: Ar-ruzz Media.

Lestari, D.E., Nizaruddin dan Murtianto, YH. (2017). Efektivitas model pembelajaran PBL berbantuan media kokami ditinjau dari gaya belajar terhadap prestasi belajar matematika. aksioma. 8(2), 68-76.

Perdana, R., Jumadi, J., dan Rosana, D. (2019). Relationship between analytical thinking skill and scientific argumentation using PBL with interactive $\mathrm{CK} \quad 12$ simulation. International Journal on Social and Education Science. 1(1), 6-23.
Qian, M., dan Clark, K. R. (2016). Gamebased learning and 21 st century skills: A review of recent research. Computers in Human Behavior. 63, 50-58

Saharsa, U., Qaddafi, M., dan Baharuddin. (2018). Efektifitas penerapan model pembelajaran problem based learning berbantukan video based laboratory terhadap peningkatan pemahaman konsep fisika. Jurnal Pendidikan Fisika. 6(2), 57-64.

Untarti, R. (2015). Efektifitas problem based learning (PBL) terhadap kemampuan pemecahan masalah mahasiswa pada mata kuliah statistika inferensia. Journal of Mathematics Education AlphaMath. 1(1), 101-112 